$\infty$

0

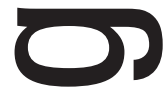

-

ת

1

$\longrightarrow$ 


\title{
A CARTOGRAFIA APLICADA AO PLANEJAMENTO DO TURISMO
}

\author{
CARTOGRAPHY APPLIED TO THE PLANNING OF TOURISM
}

\author{
Ivanilton José de Oliveira - UFG \\ oliveira@iesa.ufg.br
}

\section{Resumo}

A cartografia é uma forma de comunicação que tem atuado na instrumentação do turismo praticamente desde o seu surgimento como atividade econômica. E assim como outras formas de comunicação com o turista, como os folhetos de divulgação e placas informativas que são disponibilizados nos espaços turísticos, os mapas devem orientar as pessoas na localização dos objetos e lugares de seu interesse. Em especial nas tarefas de planejamento e gestão do turismo, a cartografia pode constituir um instrumental extremamente útil nas etapas de diagnóstico, de implementação e de avaliação de uma atividade turística. Contudo, a linguagem cartográfica tem uma série de especificidades que devem ser conhecidas por quem deseja utilizá-la. Este artigo pretende contribuir com a discussão sobre as relações entre a cartografia e 0 turismo, a partir da abordagem das características inerentes à linguagem cartográfica e que devem orientar a construção de mapas temáticos voltados para o planejamento do turismo.

Palavras-chaves: cartografia do turismo, planejamento do turismo, linguagem cartográfica.

\begin{abstract}
Cartography is a communication form used in the instrumentation of tourism practically since its appearance as social and economic activity. Like other types of communication with tourists, as the brochures, posters and informative panels that are available in the tourist spaces, the maps must guide the people in the localization of objects and places of its interest. Specially in planning and management of tourism, cartography can constitute an extremely useful instrument in the stages of diagnosis, implementation and evaluation of a tourist activity. However, cartographic language has a series of special characteristics that must be known by who desires to use it. This article intends to contribute with the quarrel on the relations between cartography and tourism, analyzing the peculiarities of the cartographic language that must guide the construction of conceived thematic maps for the planning of tourism.
\end{abstract}

Keywords: cartography of the tourism, planning of tourism, cartographic language. 


\section{Considerações preliminares sobre a linguagem cartográfica}

Para contribuir com o planejamento do turismo a Cartografia deve ser pensada a partir do emprego dos mapas nas etapas de diagnóstico da potencialidade turística de um determinado lugar ou para a implantação de um espaço turístico (mapas para o turismo), da implementação ou consolidação de uma atividade turística (mapas para turistas) ou da avaliação dessa atividade (mapas sobre o turismo). Em todos os casos, a Cartografia deve adequar sua linguagem ao tipo de representação que será construída.

Conforme os dizeres de Teixeira Neto (1986) e Martinelli (1991, 1997), pautados nos trabalhos do pesquisador francês Jacques Bertin (1973), é preciso considerar o mapa como uma representação gráfica, forma particular de comunicação visual cuja principal característica é a monossemia. Isto significa que o mapa, ao transmitir uma informação, não deve dar margem a ambigüidades: todo usuário de uma representação cartográfica deve ser capaz de compreender a mesma mensagem, desde que consiga decodificar as relações de proporção, de ordem ou de seletividade expressas nos signos utilizados na legenda e lançados sobre o mapa.

Como se vale de uma linguagem visual, a cartografia apresenta a propriedade de ser um sistema espacial, de percepção instantânea. Quando se olha para um mapa, o que chama a atenção primeiramente é a imagem formada pelo conjunto de signos: cores, formas, texturas, tonalidades. Difere, portanto, da linguagem sonora, em que o conjunto dos signos só é apreendido linearmente: as letras formam sílabas, que formam palavras, que formam frases, que formam orações e assim por diante. A mensagem é completada apenas ao final desse encadeamento.

A compreensão da mensagem cartográfica, contudo, depende da utilização dos dois sistemas de percepção, o sonoro e o visual. O primeiro aparece no título, indicando o lugar, o tema e o recorte temporal, aos quais se referem os dados representados no mapa. Aparece também na legenda, expressando o significado de cada cor, forma ou textura, e ainda na toponímia, os nomes dos lugares lançados diretamente sobre o mapa.

Nesse aspecto, convém destacar que o arranjo dos signos (sílabas, palavras, frases etc.) no título, na legenda, na toponímia e em outras informações textuais (fontes, autores etc.) será compreensível apenas para aqueles que dominam o idioma no qual eles são expressos. Isso torna a linguagem sonora particular: a compreensão da mensagem exige que o leitor esteja familiarizado com a forma de estruturação dos signos no idioma em que eles são expressos. 
Por outro lado, de acordo com Joly (1990, p. 13), a linguagem visual apresenta a propriedade de ser universal, "no sentido em que utiliza uma gama de símbolos compreensíveis por todos, com um mínimo de iniciação”. Talvez o correto seja dizer que alguns signos, por remeterem diretamente à idéia de um objeto real, representando suas formas, ou por ganharem um valor simbólico, de cunho cultural, construído historicamente, permitem sua compreensão de maneira imediata, sem a necessidade de uma legenda (Figura 1).

Figura 1: Exemplos de signos visuais com valor simbólico.

$8 \mathrm{x}, 000$

Contudo, essa "universalidade" deve ser vista com reservas. Assim como não é possível encontrar signos que dêem conta da representação de todos os objetos ou fenômenos com os quais estabelecemos relações ao longo de nossas vidas, é preciso ter claro que vários signos perdem o valor simbólico quando retirados de seu contexto histórico ou sociocultural: o objeto referente pode não existir (ou deixar de existir) em outro contexto ou o significado atribuído ao signo não é o mesmo, quando muda o contexto. Assim, uma cor que é símbolo do luto numa sociedade, pode não sê-lo em outra. Da mesma forma, o desenho de um avião, que hoje é facilmente reconhecido em mapas para indicar pistas de pouso ou aeroportos, pode perder seu significado no futuro, quando esse aparelho deixar de existir.

Isso indica que a cartografia - e aqui se inclui uma cartografia do turismo - jamais constituirá uma linguagem expressa a partir de signos realmente universais. A cartografia é uma construção cultural, portanto, espelha um contexto histórico, social, econômico e político. E está em constante mudança, como toda a cultura.

A preocupação de quem vai construir um mapa está em saber retratar as relações que se estabelecem entre os objetos e os fenômenos, conforme preconizam Teixeira Neto (1986) e Martinelli (1991, 1996, 1997), e não a exaltação das relações entre significante (o estímulo físico, o desenho) e significado (a idéia).

Para esses autores, mais importante do que buscar signos que dêem conta de remeter à idéia dos objetos referentes (aqueles que devem ser representados no mapa) é buscar retratar visualmente as relações que tais objetos 
podem apresentar entre si, que podem ser descritas como relações de proporção, de ordem ou de diversidade. Assim, trata-se de escolher os signos que dêem conta de representar tais relações.

Bertin (1973), a partir de uma série de estudos de percepção visual, apresenta uma tabela de variáveis visuais, que têm a propriedade de transcrever visualmente as relações de proporção, ordem e diversidade, em suas manifestações pontuais, quando a área desses objetos ou fenômenos é insignificante para ser representada numa determinada escala e eles são vistos como pontos; lineares, quando a largura é insignificante em relação ao comprimento e os objetos ou fenômenos se apresentam na forma de linhas ou traços; ou zonais, quando os objetos ou fenômenos preenchem áreas, passíveis de serem representadas (Figura 2).

Figura 2: As variáveis visuais ou retinianas. Adaptado de Bertin (1973).

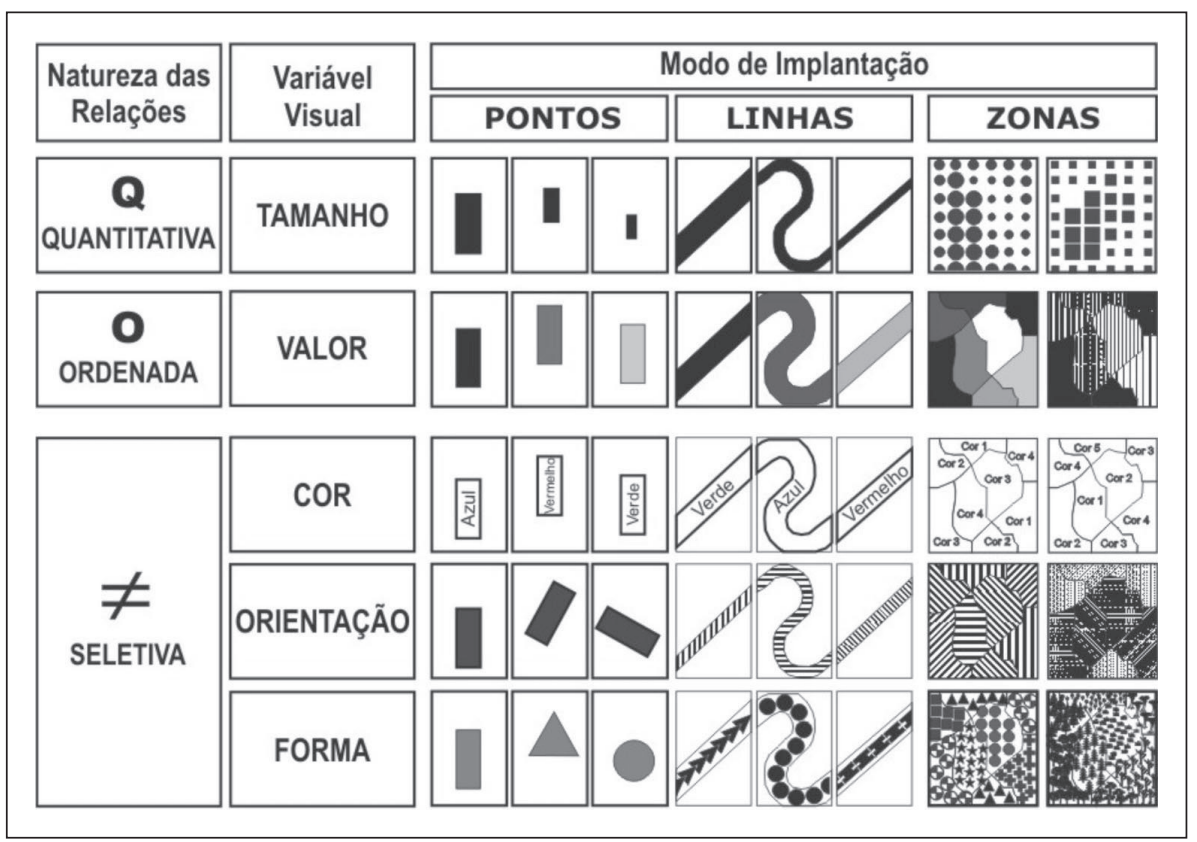

A tabela original, do pesquisador francês, apresenta ainda a variável granulação, que indica a variação da espessura de hachuras pretas num fundo branco, sempre numa mesma proporção, criando uma textura. Ela foi excluída da tabela que é apresentada neste artigo em função de sua pouca 
aplicabilidade, já que ela é fracamente ordenada e pouco seletiva, além de confundir-se com a variável visual valor. Em geral, outros autores têm indicado sua substituição por uma variável chamada simplesmente de textura.

Conforme se pode observar, cada variável visual é indicada para um determinado nível perceptivo: enquanto tamanho é a única variável capaz de transcrever visualmente a noção de proporção, característica dos dados quantitativos, a variável valor é a mais indicada para transcrever a noção de ordem, com a hierarquia dos dados sendo apresentada por uma variação do claro para o escuro. Já as demais variáveis, cor, orientação e forma, são indicadas para dados que não apresentam nem proporção e nem ordem, ou seja, são apenas de caráter seletivo: a diversidade dos objetos ou fenômenos é transcrita por uma diversidade de cores, formas ou orientações, combinadas ou não.

Essas variáveis devem ser empregadas na construção da legenda e, posteriormente, aplicadas ao mapa. A escolha correta da variável garantirá que a transcrição visual seja fiel à natureza original das relações entre os dados, sem margem para a transmissão de mensagens errôneas ou ambíguas.

No caso específico do turismo, dependendo do tipo de informação a ser transmitida nas fases de diagnóstico, implementação ou avaliação do turismo, poderão ser elaborados mapas que trabalharão mais com dados de natureza seletiva ou ordenada ou quantitativa.

\section{A cartografia como instrumento de diagnóstico das potencialidades turísticas: mapas para o turismo}

Na etapa de diagnóstico do turismo, quando se levanta o potencial de determinado lugar para tornar-se um atrativo turístico ou quando é feita a escolha de lugares potenciais para a instalação de um empreendimento turístico (como resorts, pousadas, parques de diversão etc.), a cartografia responde pela elaboração de mapas básicos, seja pela compilação de cartas e mapas já existentes, seja pelo trabalho com fontes primárias para a geração de novos mapas.

As fontes primárias referem-se ao trabalho de coleta de dados em campo, com o uso de receptores GPS (Global Positioning System, sistema global de posicionamento), bússola e outros instrumentos, para delimitação de uma área de interesse, localização de certos atrativos potenciais e levantamento de informações da configuração espacial (como as formas de ocupação das terras); a interpretação de imagens orbitais e fotografias aéreas, com a mesma 
finalidade; e, ainda, a aplicação de questionários e entrevistas, visando obter dados sobre as características atuais dos espaços analisados.

Já as fontes secundárias referem-se aos mapas já existentes, como os levantamentos cartográficos do Instituto Brasileiro de Geografia e Estatística (IBGE) e da Diretoria do Serviço Geográfico do Exército (DSG), de órgãos estaduais e municipais ou de empresas privadas, além de universidades e instituições de pesquisa. Também são fontes secundárias os dados tabulares e textuais elaborados por essas entidades, como por exemplo, os censos demográficos e agropecuários e os anuários estatísticos, os relatórios técnicos, os artigos, as monografias, as dissertações e as teses.

Entre os mapas temáticos básicos que podem ser elaborados a partir dessas fontes, podem-se citar os de uso e ocupação das terras, da infra-estrutura disponível, das formas do relevo, dos elementos climáticos, entre outros.

Os mapas de uso e ocupação das terras representam as atividades econômicas já instaladas sobre determinado território, como a agricultura, a pecuária, as áreas urbanas, a malha viária e as áreas verdes remanescentes. O grau de detalhamento das classes escolhidas vai depender da escala do mapeamento e de sua relevância para o empreendimento turístico a ser instalado.

Os mapas sobre a infra-estrutura mostram a localização de elementos como a rede viária, as redes de energia elétrica, telefonia, água tratada, coleta de esgoto, TV a cabo etc., além da localização de serviços essenciais, como a presença de agências dos correios, postos de saúde ou hospitais, agências bancárias, postos policiais ou delegacias e postos de combustíveis.

Mapas sobre o relevo, como os morfológicos ${ }^{1}$, os clinométricos ${ }^{2}$ e os hipsométricos ${ }^{3}$, apresentam características fisiográficas sobre as paisagens que permitem, por exemplo, observar as restrições à instalação de determinadas formas de ocupação, como edificações de grande porte, abertura de estradas, construção de barragens etc. Eles se conjugam aos mapas geotécnicos e geológicos, dependendo do tipo de empreendimento. Contudo, é preferível que tais mapas sejam acompanhados por representações cartográficas de síntese das características naturais, como os mapas de unidades ambientais ou unidades de paisagem, em que são consideradas as características integradas da geologia, do clima, do relevo, dos solos e da vegetação.

Mapas sobre os elementos do clima são particularmente importantes para áreas com potencial para a instalação do turismo de lazer, como pousadas e hotéis ou outros tipos de empreendimentos em balneários ou em ambientes de altitudes mais elevadas. Enfim, qualquer atividade em que sejam relevantes as informações sobre a distribuição anual das chuvas, dias 
com insolação, direção e intensidade dos ventos ou a variação anual das temperaturas.

A partir dos mapas básicos ou sobre eles pode-se localizar e destacar os possíveis atrativos turísticos e, após espacializados, relacioná-los com as características naturais ou socioeconômicas do lugar para avaliar o grau de sua potencialidade e detectar prováveis problemas a serem superados em sua efetivação como atrativos.

Num exemplo simples, um mapa com a topografia de uma área, expressando as altitudes em curvas de nível e pontos cotados, quando cruzado com a rede de drenagens pode dar indicativos da presença de quedas d'água, cachoeiras e corredeiras, que são atrativos naturais em potencial. Para maior detalhamento, pode-se associar também o uso de imagens orbitais ou fotografias aéreas (Figura 3). A partir daí, o cruzamento com as informações sobre a infra-estrutura disponível nas proximidades do local (rede viária, hotéis, postos de combustíveis, entre outros) e sobre os tipos de uso e ocupação das terras na região, pode determinar a viabilidade ou não de eleger tal lugar como um atrativo e qual a sua potencialidade.

Figura 3: Imagem de satélite combinada com dados altimétricos e a rede de drenagens.

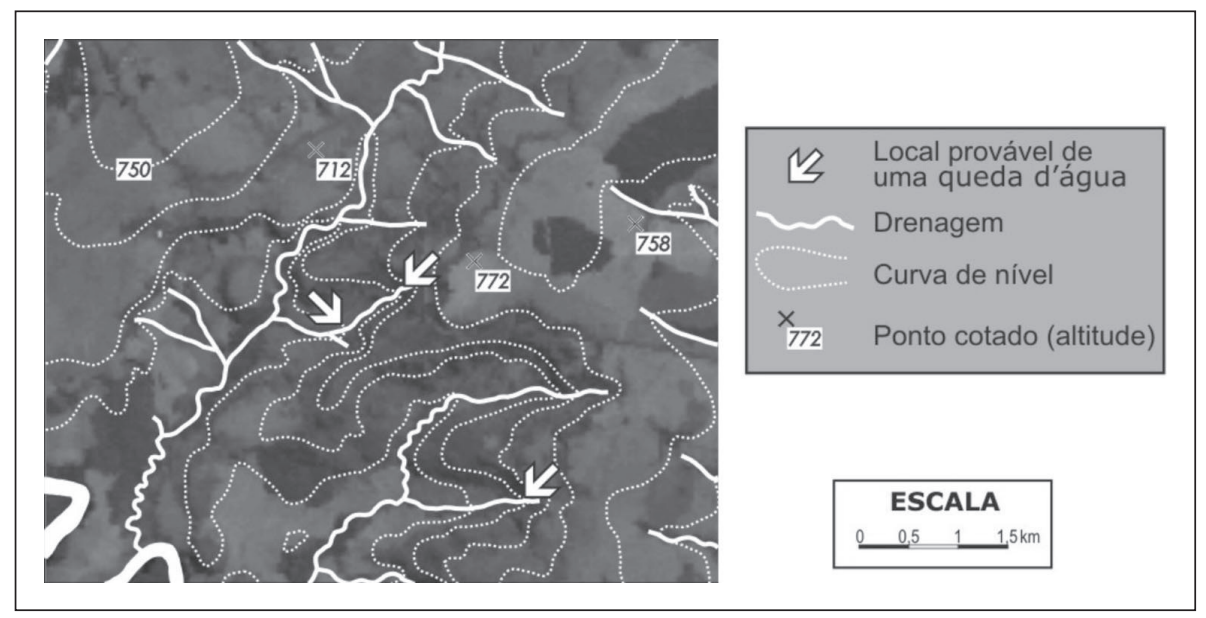

O uso do geoprocessamento nessa etapa do planejamento significa um ganho considerável, especialmente a partir do cruzamento dos mapas temáticos básicos utilizando-se sistemas de informações geográficas (SIG). Uma 
das grandes vantagens desses sistemas é o fato de permitirem a integração de dados de diversas fontes numa mesma base, inclusive comunicando diversas escalas e distintas projeções.

Com um SIG é possível, por exemplo, realizar uma análise de proximidade, para indicar quantos estabelecimentos comerciais (como postos de combustíveis ou hotéis) são encontrados ao longo de uma rodovia, numa faixa de 500 ou $1.000 \mathrm{~m}$ de largura a partir de suas margens. Pode-se realizar o cruzamento de informações de um mapa de uso e ocupação das terras com outro que localiza os possíveis atrativos da região, a fim de se verificar os problemas quanto à incongruência de uso (o lugar tem uma potencialidade turística como balneário, mas é utilizado para a extração de areia, por exemplo). Alguns parâmetros metodológicos são indicados por Veiga e Xavier-daSilva (2004), para procedimentos de identificação de áreas com potencial para atividades turísticas, a partir do uso do geoprocessamento.

Enfim, há uma gama enorme de possibilidades de análises e avaliações que podem ser facilmente realizadas, poupando tempo e recursos humanos. Exigem, contudo, que o planejador saiba o que precisa, pode ou deve ser correlacionado, analisado e avaliado, pois um SIG é uma ferramenta que não pensa sobre o problema, apenas executa aquilo que o operador lhe indica numa seqüência de comandos.

\section{A cartografia como subsídio à implementação das atividades turísticas: mapas para turistas}

A primeira função de um mapa para turistas é localizar, com precisão e clareza, onde estão os atrativos turísticos num determinado lugar. Portanto, na escolha dos elementos da paisagem que devem constar no mapa é preciso considerar a necessidade de filtrar informações desnecessárias, que apenas tornariam o mapa carregado visualmente e dificultariam a localização dos atrativos.

O mapa deve ser visto como forma de comunicação com o turista. Precisa, portanto, utilizar uma linguagem adequada ao tipo de turista que deverá manuseá-lo, sob pena de ser descartado ou virar uma peça meramente ilustrativa.

O processo de comunicação visual com o turista obedece, na maior parte dos casos, o mesmo princípio estabelecido na teoria sistêmica da comunicação, ou seja, a relação entre um emissor, a mensagem e um receptor (Figura 4). 
Figura 4: Processo esquemático da comunicação cartográfica. Adaptado de Duarte (1991).

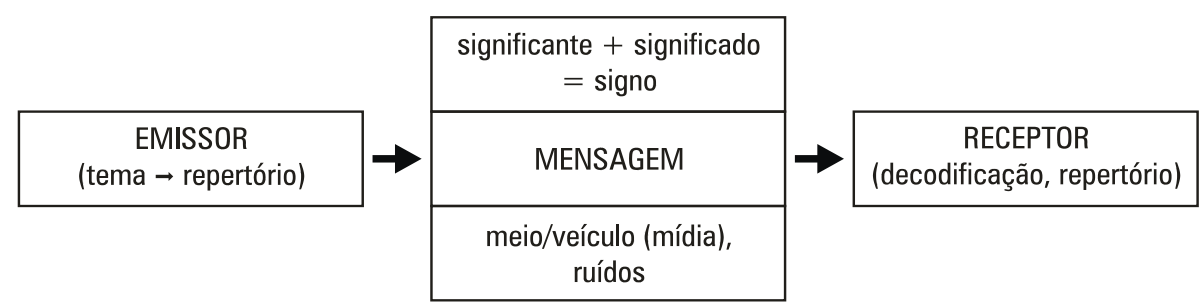

Essa relação pode ser exemplificada da seguinte forma: supondo-se a necessidade de construir um mapa que demonstre quais os municípios turísticos de Goiás, a pessoa que irá construir o mapa (o emissor) deve valer-se de seu repertório sobre o assunto: os conhecimentos que já dispõe ou que deve buscar, em fontes primárias ou secundárias, sobre quais são esses municípios e que tipo de turismo ocorre em cada um deles.

A partir daí, o emissor precisa definir como será a legenda do mapa: com símbolos diferentes para cada tipo de turismo ou formas idênticas variando apenas as cores? Ou uma combinação das duas coisas? Os símbolos (ou cores) deverão preencher a área de cada município (implantação zonal) ou bastará apenas um símbolo em cada município (implantação pontual)? Devem-se destacar os municípios turísticos dos demais, com uma coloração diferenciada, ou isso não é necessário?

O receptor ou leitor do mapa, por sua vez, dependerá de seus próprios conhecimentos sobre o tema para se familiarizar com o que é representado no mapa. Muito embora a finalidade do mapa seja fazer com que qualquer leitor entenda a idéia elaborada por quem o construiu, sabe-se que o processo de comunicação só é estabelecido sem maiores perdas quando a linguagem é adequada. Ou seja, quando o leitor ou usuário final do mapa for capaz de decodificar a legenda e, assim, entender o que significam as cores e formas lançadas sobre o mapa, como elas se distribuem (sua localização geográfica) e possa, ainda, estabelecer raciocínios espaciais, como por exemplo: há uma concentração dos tipos de turismo em determinado lugar, ou há um predomínio de um tipo de turismo numa determinada região geográfica etc.

A aplicação incorreta das variáveis visuais ou do modo de implantação ou ainda o tratamento incorreto dos dados originais pode provocar "ruídos” na comunicação com o leitor. Munari (2001) afirma ainda que, mesmo 
quando a mensagem visual é projetada de tal modo que evite qualquer deformação durante a emissão, cada receptor, e cada um de um modo diferente, possui "filtros", através dos quais a mensagem terá de passar para ser percebida. Para o autor, esses filtros são de caráter sensorial (como a sensibilidade às cores), funcional (as características psicofisiológicas de cada pessoa, como o desenvolvimento intelectual em cada faixa etária) e cultural (a carga de informações e conceitos inerentes ao universo cultural do receptor). Os filtros, por sua vez, não são rigorosamente distintos e não agem necessariamente na ordem descrita.

No caso do uso de mapas, há também a necessidade de uma alfabetização cartográfica do destinatário ou receptor, a fim de que ele possa reconhecer, sem maiores problemas, a abstração que é utilizada no mapa, em que a visão da paisagem é vertical - de cima para baixo (Figura 5) - e signos são utilizados para substituir os objetos verdadeiros, representados de forma muito reduzida (a escala do mapa).

Figura 5: Da visão lateral ou oblíqua do objeto à abstração da visão vertical (como num mapa ou foto).

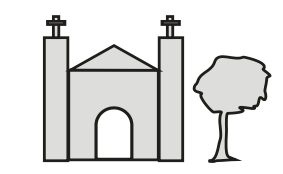

Visão Lateral

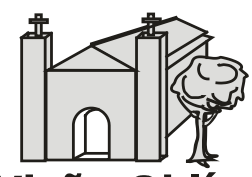

Visão Oblíqua

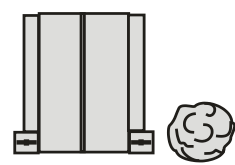

Visão Vertical

Embora saibamos que essa alfabetização cartográfica não é adequadamente trabalhada na educação formal, é possível construir mapas que cumpram corretamente a função de comunicar o turismo, desde que observada a premissa básica de que há diferentes tipos de turismo e, portanto, diferentes tipos de turistas. Logo, é preciso haver também uma diversidade de mapas turísticos.

O turismo de lazer, realizado nos fins de semana por pessoas que vão a cidades históricas ou a balneários, por exemplo, geralmente exige que os mapas apenas consigam orientar os turistas a localizar um determinado atrativo, guiando-se por referenciais visíveis na paisagem. Portanto, qual seria a função de uma rede de coordenadas geográficas, com paralelos e meridianos indicando as latitudes e longitudes do lugar? 
Difere, em outro exemplo, da situação do turismo de aventura, quando o turista é levado a guiar-se por um lugar sem referenciais facilmente reconhecíveis, como uma floresta, ou quando esse é o objetivo da própria atividade turística: fazer com que as pessoas saibam orientar-se a partir do uso de bússolas ou de receptores GPS. Nesses casos, os mapas devem, obrigatoriamente, trazer referenciais claros de coordenadas geográficas e de orientação geográfica (a indicação das direções cardeais).

No caso da representação dos elementos ou objetos no mapa, como os próprios atrativos turísticos, a visualização é facilitada para turistas que não têm o hábito da leitura de mapas (a imensa maioria) quando tais elementos aparecem numa visão lateral/frontal ou oblíqua (como se vistos de um plano elevado) e em desenhos que se assemelhem aos objetos reais - as representações iconográficas ou pictóricas (Figuras 6 e 7).

Figura 6: Representações pictóricas que remetem a serviços e observação de animais.
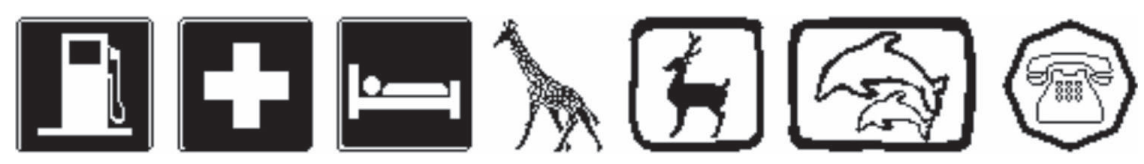

Figura 7: Passagem da representação fotográfica para um signo pictórico.

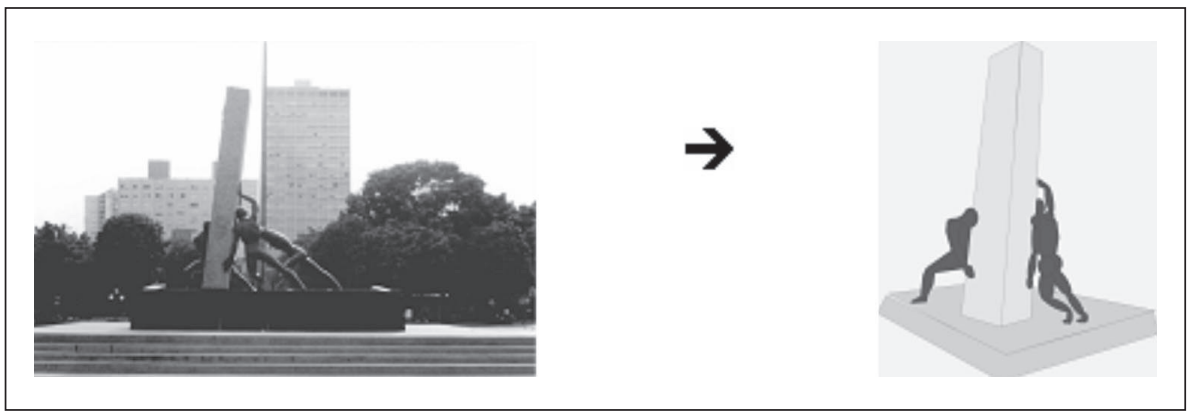

Já para turistas habituados ao uso de mapas, a visão vertical dos atrativos, com os objetos vistos de cima para baixo e com o uso de representações abstratas, como formas geométricas básicas (Figura 8), surte o mesmo resultado. 
Figura 8: Representações com signos geométricos para identificar elementos num espaço turístico.

\section{$\square=$ Museu $\bigcirc=$ Monumento $X=$ Centro de informação ${ }_{=}$Parada de ônibus}

Martinelli $(1996,2001,2002)$ advoga que à legenda podem ser apostas também fotografias dos respectivos argumentos dos significados dos signos, o que enriquece em muito o mapa, possibilitando maior aproximação do grande público ao seu conteúdo e garantindo-lhe maior alcance social.

A principal preocupação de quem irá construir tais mapas deve ser a transcrição das relações originais existentes entre os objetos (os atrativos), utilizando variáveis visuais (cores, formas, texturas) iguais para atrativos de um mesmo grupo, modificando-as para os demais grupos de atrativos, sem atribuir a idéia de ordem ou de proporcionalidade entre os objetos, quando não existirem tais relações entre eles.

Os mapas para turistas são essencialmente mapas que representam relações de diversidade entre objetos. Isto significa que a escolha das variáveis visuais para construção da legenda e sua aplicação no mapa devem ressaltar as relações de diversidade visual existentes entre os dados, isto é, devem-se exaltar os diferentes tipos de turismo ou diferentes atrativos turísticos a partir da escolha de cores, formas, orientações ou texturas, considerando ainda a forma de implantação no mapa, se pontual, linear ou zonal.

O objetivo de um mapa é fazer com que leitor recorra o menos possível à legenda no processo de leitura. Para tanto, uma preocupação a ser observada refere-se à quantidade de signos na legenda, quando o mapa estampar uma gama muito grande de informações. Quanto maior o número de signos, mais difícil será a memorização de todos eles e, portanto, também a visualização de sua ocorrência no mapa. Ao mesmo tempo, a tentativa de agrupar diversas classes, atribuindo-lhes um mesmo signo, pode mascarar a informação original, significando um filtro a mais na transcrição da situação real encontrada e que deveria ser retratada.

Essa é sempre uma escolha difícil: representar tudo aquilo que é encontrado no mundo real, mas tornando a leitura do mapa extremamente difícil, ou filtrar alguns elementos, não os representando ou agrupando-os, mas sacrificando parte das informações originais? Tudo dependerá do objetivo 
final a que se destina o mapa, a quem ele servirá, como poderá ou deverá ser utilizado. É preciso sempre lembrar que a representação cartográfica implica num certo grau de subjetividade, em que a comunicação é portadora de uma carga ideológica, mesmo que, muitas vezes, nem o seu construtor nem o usuário do mapa estejam plenamente conscientes disso.

\section{A cartografia como instrumento de avaliação da atividade turística: mapas sobre 0 turismo}

A cartografia pode dar uma contribuição significativa ao processo de análise das atividades turísticas já implementadas. A comunicação visual consegue destacar de forma mais direta os elementos relativos à exploração do turismo sobre determinada área, facilitando a avaliação dos aspectos positivos e negativos que porventura estejam ocorrendo, e também sua relação com outras variáveis que igualmente possam ser espacializadas.

A atividade turística, vista a partir de seu viés econômico, isto é, como uma atividade economicamente produtiva, envolve a necessidade da geração de lucro, sem o qual deixa de ser atrativa para o capital. Portanto, como nos demais setores de serviços, o turismo precisa ser constantemente avaliado, para se apontar as falhas que possam estar atrapalhando a consolidação da atividade turística, como pontos de estrangulamento; indicar a necessidade de eventuais correções no ritmo, na direção ou na forma como a atividade é desenvolvida, para prevenir o surgimento ou ampliação de problemas; e, por fim, apresentar alternativas de renovação que garantam a permanência de sua atratividade, já que há uma tendência à perda do poder de atração, na medida em que novos lugares surjam, com diferenciais de custo ou de oferta de elementos atrativos.

Nesse aspecto, a cartografia deve trabalhar especialmente com dados de natureza quantitativa, que espelhem a mensuração da atividade turística sob vários aspectos, como: o número de turistas que freqüentam determinado atrativo, o seu lugar de origem, as suas características econômicas (renda, poder aquisitivo), socioculturais (formação educacional, interesses culturais etc.); a infraestrutura disponível para uso dos turistas, como o número de hotéis (sua classificação quanto à qualidade dos serviços ofertados (Figura 9), quantidade de quartos disponíveis etc.), características do acesso (rodoviário, ferroviário, aeroviário e aquaviário), sinalização (placas de direção e placas informativas), atividades comerciais e de serviços aces- 
sórios (agências bancárias, correios, comércio tradicional etc.), entre outros elementos.

Figura 9: Mapa da classificação dos hotéis na região central de Goiânia.

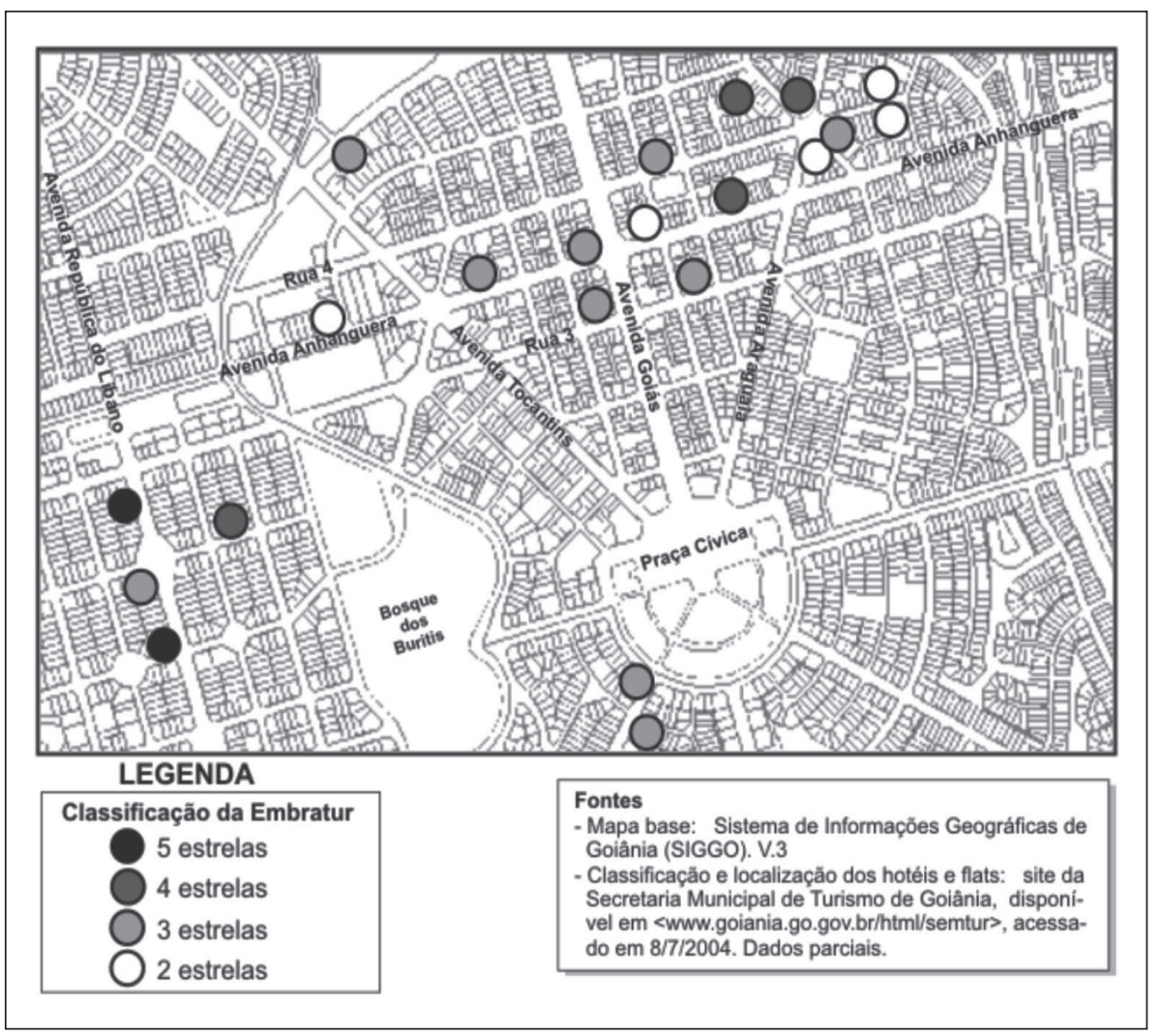

Um dos grandes problemas na manutenção de atividades comerciais e de serviços no Brasil tem sido a falta de um planejamento prévio, que anteceda a implantação de tais atividades, o que muitas vezes leva à rápida saturação na oferta e conseqüente quebra de um empreendimento, já que muitos se aventuram, ao mesmo tempo, numa mesma atividade, tida como lucrativa naquele momento.

Mas a manutenção de um empreendimento turístico, assim como os de outras modalidades, também deve prever um constante acompanhamento do padrão dos serviços ofertados e sua relação com o grau de satisfação 
dos usuários - os turistas. Para tanto, é preciso a coleta sistemática de dados sobre a atividade turística. O que temos visto, contudo, é que tais dados são negligenciados ou buscados apenas circunstancialmente, a partir de pesquisas isoladas, muitas de caráter acadêmico ou sob a ação de agentes governamentais, e não como uma política empresarial.

Esse é um erro que precisa ser evitado. Embora os dados de pesquisas acadêmicas e governamentais muitas vezes subsidiem as políticas públicas (ou privadas) relativas ao turismo, deveria ser uma preocupação também das pessoas envolvidas diretamente com a atividade turística a geração de informações sobre a demanda por determinado atrativo, a qualidade dos serviços prestados às pessoas que o buscam, o grau de satisfação de quem o usufrui, a renda gerada pela atividade turística, os gastos envolvidos na sua manutenção, entre outras variáveis.

E é com base nesses dados que a Cartografia pode trabalhar, espacializando informações que deverão subsidiar estudos mais aprofundados sobre o desenvolvimento da atividade turística e sua sustentabilidade econômica, ambiental e social.

Exemplos desse trabalho seriam mapas que mostram como é o fluxo de turistas em trilhas ecológicas num parque, a fim de determinar os pontos mais visitados e o surgimento de problemas, como erosões lineares, para subsidiar uma discussão sobre a capacidade de carga; a distribuição geográfica da capacidade hoteleira de uma cidade e sua qualificação, em relação à localização dos atrativos turísticos disponíveis no local, para determinar possíveis problemas quanto ao acesso; ou em relação ao número de turistas que freqüentam a cidade em determinado período de tempo, para determinar a ociosidade e os momentos de estrangulamento.

Em todos os casos, os mapas servem como instrumentos de gestão, apoiando a definição de políticas de incremento ao turismo e, ao mesmo tempo, racionalizando tal atividade. Isso não implica numa visão meramente economicista, embora isso possa ocorrer. Como já foi dito, mapas são instrumentos ideológicos.

Nada impede, porém, que a cartografia possa ser utilizada também como um instrumento a serviço da qualificação do turismo não só como atividade geradora de renda para alguns, mas principalmente como instrumento de melhoria das condições econômicas de muitos, de divulgação de valores culturais libertos de pré-conceitos e com uma função educadora, voltada para a mudança nos padrões de consumo atualmente vigentes. Enfim, como um instrumento de eqüidade social. 


\section{Considerações finais}

A construção de mapas temáticos envolve a observação de algumas regras básicas, que foram abordadas de forma sucinta neste artigo. Embora sejam indicações simples, o que permite a qualquer pessoa ser capaz de construir uma representação temática, é preciso tomar alguns cuidados na escolha das bases cartográficas que serão utilizadas.

Os mapas disponíveis em escalas médias ou pequenas (e.g.: áreas de municípios ou unidades da federação), referentes ao território brasileiro, são oriundos de órgãos governamentais, como o IBGE e a DSG. Atualmente é possível adquirir essas bases cartográficas em meio digital, o que facilita bastante o manuseio para a construção dos mapas temáticos e, também, a reprodução posterior.

Mapas em escalas maiores, como as delimitações intra-municipais, áreas urbanas, propriedades rurais, entre outros exemplos, já apresentam um grau de dificuldade muito maior em sua aquisição, pois não há, no Brasil, uma política nacional de mapeamento do território e tampouco entre os níveis estadual e municipal. São poucos os municípios brasileiros que dispõem de uma malha cartográfica atualizada e, entre os que a possuem, a maioria refere-se apenas à área urbana, negligenciando o espaço rural.

Em muitos casos, portanto, haverá a necessidade da contratação de profissionais adequados para a confecção de mapas de base, como topógrafos, agrimensores, engenheiros cartógrafos ou geógrafos. Essa decisão deve ser precedida de um bom levantamento de fontes secundárias, como já indicado anteriormente, pois há um desconhecimento acerca dos acervos cartográficos já existentes, haja vista a falta de comunicação entre os diversos órgãos que estão capacitados a realizar mapeamentos dessa natureza.

Não menos importante, contudo, é a pessoa envolvida com o planejamento do turismo saber da potencialidade da cartografia nessa atividade, saber explorá-la adequadamente, de forma crítica e consciente. Espera-se que o presente artigo tenha contribuído para isso.

\section{Notas}

1 Mapas morfológicos representam as formas do relevo, como vertentes côncavas, convexas ou retilíneas.

2 Mapas clinométricos ou de declividade demonstram as variações de inclinação do relevo, em graus ou porcentagens.

3 Mapas hipsométricos representam o relevo a partir das faixas de altitudes. 


\section{Referências}

BERTIN, Jacques. La sémiologie graphique. Paris-La Haye: Moutonn-Gauthier-Villars, 1973.

DUARTE, Paulo Araújo. Cartografia temática. Florianópolis: Ed. da UFSC, 1991.

JOLY, Fernand. A cartografia. Trad. Tânia Pellegrini. Campinas: Papirus, 1990.

MARTINELLI, Marcello; RIBEIRO, Monica Patrícia. Cartografia para o turismo: símbolo ou linguagem gráfica. In: RODRIGUES, Adyr Balastreri (Org.). Turismo e desenvolvimento local. 3. ed. São Paulo: Hucitec, 2002.

MARTINELLI, Marcello. Cartografia do turismo e imaginário. In: RODRIGUES, Adyr B. (Org.). Turismo rural. São Paulo: Contexto, 2001.

MARTINELLI, Marcello. Gráficos e mapas: construa-os você mesmo. São Paulo: Moderna, 1997.

MARTINELLI, Marcello. Cartografia do turismo: que cartografia é essa. In: LEMOS, Amalia I. G. de (Org.). Turismo: impactos socioambientais. São Paulo: Hucitec, 1996.

MARTINELLI, Marcello. Curso de cartografia temática. São Paulo: Contexto, 1991.

MUNARI, Brunno. Design e comunicação visual: contribuição para uma metodologia didática. trad. Daniel Santana. São Paulo: Martins Fontes, 1997.

TEIXEIRA NETO, Antônio. Haverá, também, uma semiologia gráfica? Boletim Goiano de Geografia, Goiânia, v. 4/5/6, n. 1/2, p. 13-54, jan./dez. 1984/85/86.

VEIGA, Teresa Cristina; XAVIER-DA-SILVA, Jorge. Geoprocessamento aplicado à identificação de áreas potenciais para atividades turísticas: o caso do município de Macaé-RJ. In: XAVIERDA-SILVA, Jorge; ZAIDAN, Ricardo Tavares (Org.). Geoprocessamento e análise ambiental: aplicações. Rio de Janeiro: Bertrand Brasil, 2004.

IVANILTON JOSÉ DE OLIVEIRA - Professor Assistente do Instituto de Estudos Socioambientais da Universidade Federal de Goiás. Doutor em Geografia pela USP

Recebido para publicação em junho 2005

Aceito para publicação em setembro 2005 